Int. J. Morphol.,

35(1):99-104, 2017.

\title{
High Exposure to Boron in Drinking Water and Sperm Parameters in Chilean Young People
}

\author{
Exposición Elevada a Boro en el Agua Potable y Parámetros de Esperma en Gente Joven Chilena
}

\author{
Sandra Cortés ${ }^{1}$; Omar Espinoza-Navarro² \& Catterina Ferreccio ${ }^{1}$
}

CORTÉS, S.; ESPINOZA-NAVARRO, O. \& FERRECCIO, C. High exposure to boron in drinking water and sperm parameters in young Chilean people. Int. J. Morphol., 35(1):99-104, 2017.

SUMMARY: Our aim was to describe sperm parameters in residents from Northern Chile. We evaluated in 101 volunteers (18 and 30 years old) urinary and drinking water Boron levels using Inductively Coupled Plasma Mass Spectrometry; semen parameters were measured with standardized methods. Each individual was categorized in 3 levels of exposure: low (B levels in urine $\leq 2.94 \mathrm{mgL}-$ 1 or tap water $\leq 3.0 \mathrm{mgL}-1$ ), medium (urinary B between 2.95-7.4 mgL-1 and B in tap water with 3.0-7.0 mgL-1) and high (urinary B > $7.4 \mathrm{mgL}-1$ or tap water $>7.0 \mathrm{mgL}-1)$. We found no significant differences among groups by $\mathrm{pH}$, sperm concentration (45.1; 48.2 and 38 million/mL), motility 1 th hour $(38.1 ; 40.0$ and $45.5 \%)$ and vitality 1 th hour $(88.6 ; 88.0$ and $76.9 \%)$ respectively. Abnormal morphology was significant different (83.3; 90 and $83 \%)$. Young men exposed to B in drinking water present sperm variations associated with the level of exposure. Most of these changes are positive at intermediate levels of B. For the highest exposures were observed negative changes in sperm morphology, concentration, motility and vitality, all relevant parameters of fertility. Beneficial effect is observed at medium exposure, like a "U curve".

KEY WORDS: Boron, Semen, Seminal Parameters, Fertility, Boron exposure, Chile

\section{INTRODUCTION}

There is growing evidence that semen parameters can be altered by different chemicals, environmental pollutants, including pesticides and metals (Giudice, 2006; Hauser, 2006; Xing et al., 2008; Sifakis et al., 2011; Telöken et al., 2012). The main semen parameters that have an important role in male fertility and are affected with various environmental exposures are sperm concentration, motility and morphology (Esteban \& Castaño, 2009; Jurewicz et al., 2009).

Special interest exists with respect to Boron and its role in reproduction. Boron is an essential trace element for animals (Nielsen, 1984; Murray, 1998). Evidence states that it helps control inflammatory processes in humans and substantially participates in the absorption of calcium in bone (Usuda et al., 2007). When high Boron doses of up to 80 $\mathrm{mg} / \mathrm{kg} /$ day were administered to animal models, adverse effects such as anorexia, weight loss, altered bones, testicular atrophy and epididymal sperm reduction were observed, especially in mice (Rose \& Cohrssen, 2010; Korkmaz et al., 2011). Either mutagenic or carcinogenic effects from exposure to this element in human normal activities have been found (Fail et al., 1998; Korkmaz et al., 2007a).

Population-based studies that have measured exposure to Boron and health effects at the population level are scarce and their findings have been inconclusive (Weinthal et al., 2005). They are made in USA, Turkey and Chine, principally in workers. Studies in male Turkish population exposed to a Boron dose of $6.7 \mathrm{mg} / \mathrm{day}$ did not find significant alterations in male fertility (Korkmaz et al., 2007b; Scialli et al., 2010). Studies relating Boron with semen parameters finds no correlation between Boron in urine, blood and semen parameters, although there was a nonsignificant increase in the percentage of normal sperm morphology in workers exposed to Boron versus a control population (Robbins et al., 2010). Similar observations have been reported in Turkish workers (Duydu, et al., 2011).

\footnotetext{
${ }^{1}$ Department of Public Health, Pontificia Universidad Católica de Chile, Santiago, Chile \& Advanced Center for Chronic Diseases, ACCDIS/FONDAP. ${ }^{2}$ Department of Biology, Universidad de Tarapacá, Arica, Chile.
} 
Other effects in human populations have been described in Chinese workers exposed to Boron concentrations from 31.3 to $125 \mathrm{mg} /$ day, reporting no reproductive changes in wives of exposed workers but showing a reduction in the $\mathrm{Y}: \mathrm{X}$ ratio in sperm of exposed workers (Scialli et al.) Similar findings were reported by Robbins who determined a decrease of the $\mathrm{Y}$ chromosomebearing cells, thus causing changes in sex ratio in the offspring towards more female sex individuals (Robbins $e t$ al., 2008).

Nowadays it has become relevant to study the health effects of environmental Boron exposure in populations. In this regard, Northern Chile $\left(13^{\circ} 28^{\prime} \mathrm{S}, 70^{\circ} 20^{\prime} \mathrm{W}\right)$ is a region naturally rich in Boron. This region is bordered to the North by Peru, to the West by the Pacific Ocean, to the East by Bolivia and to the South by the Antofagasta Region and has a population of 175,603 inhabitants. The natural sources of water for the city are the Lluta River, which rises in the Andes and flows into the Pacific Ocean, and the wells of the Azapa Valley. These two bodies of water are the only source of drinking water for the city. The community of Arica has expressed concern about possible health damage caused by high levels of boron in their drinking water that presently exceeds the levels recommended by the World Health Organization (WHO, 1993). In response to the need to create a regulatory standard for boron in drinking water, the Ministry of Health of the Republic of Chile commissioned the project titled "Assessment of Boron Exposure in Drinking Water and its Effects on Health in the Municipality of Arica" and has two parts. The first component study tests exposure to Boron in drinking water, food and urine. High levels of this element in tap water ranged from 0.22 to $11.3 \mathrm{mgL}-1$ while Boron in urine ranged from 0.45 to $17.4 \mathrm{mgL}-1$ (Cortés et al., 2011). Results no published on B in more frequently used foods shows values between 0.01 and $22 \mathrm{mgKg}-1$; according our data mean daily boron intake was principally due by drinking water $(60 \%)$.
The second component evaluates health effects on reproductive health. This manuscript reports the results of second component focused on the effects in health in young males; we are working in the results of effects in 3000 pregnant females and their newborns. Our objective was to explore an association between urinary or tap water Boron levels and semen parameters of a group of healthy young males, volunteers and residing in Arica, Chile.

\section{MATERIAL AND METHOD}

Selection of participants. The study was conducted as part of a study funded by the Chilean Ministry of Health. The objective was to evaluate the health effects of exposure to Boron in tap water. Young men were invited to attend to assess their sperm quality. The target group was 400 young men aged 18 to 30 years, enrolled at the University of Tarapacá, Arica, Chile. A convenience sample was set at 100 subjects ( $25 \%$ of the group), plus $10 \%$ to cover possible losses. Selection criteria to enter into the study were to reside in Arica for at least 6 months, to be healthy and to have four days of sexual abstinence. We excluded subjects who reported having any andrological health problem, i.e. prior cryptorchidism and varicocele that may affect the semen analysis. A total of 101 eligible participants were entered in the study. All the participants that were invited accepted to participate. Each young man was informed of the nature of the study and asked to sign an informed consent. Those who accepted were instructed to take a morning first void urine sample and to bring a tap water sample from their houses; details of this method have been previously reported. They brought the samples to the Laboratory of Reproductive Biology of the University of Tarapacá, where they answered an epidemiological questionnaire about demographics aspects, residence, health history, occupational and reproductive history, smoking, use of alcohol, tap water and

Table I. Urinary or tap water Boron levels and general characteristics in voluntary participants, Arica, Chile.

\begin{tabular}{|c|c|c|c|c|c|c|c|c|c|}
\hline \multirow[t]{2}{*}{ Characteristics } & \multicolumn{2}{|c|}{$\begin{array}{l}\text { Low exposure }\left(\mathrm{mgL}^{-1}\right) \\
\text { B Urine } \leq 2.94 \text { or } \\
\text { B tap water } \\
\leq 3.0 \\
\mathrm{n}=21\end{array}$} & \multicolumn{2}{|c|}{$\begin{array}{c}\text { Medium }\left(\mathrm{mgL}^{-1}\right) \\
\text { B Urine } 2.95-7.4 \text { and } \\
\text { B tap water } \\
3.0-7.0 \\
\mathrm{n}=41\end{array}$} & \multicolumn{2}{|c|}{$\begin{array}{c}\text { High }\left(\mathrm{mgL}^{-1}\right) \\
\text { B in urine } 7.4-17.4 \text { or } \\
\text { B tap water } 7-11.0 \\
\mathrm{n}=39\end{array}$} & \multicolumn{3}{|c|}{ Total } \\
\hline & $\mathrm{n}$ & $\%$ & $\mathrm{n}$ & $\%$ & $\mathrm{n}$ & $\%$ & $\mathrm{n}$ & $\%$ & P-value \\
\hline Drink alc ohol (Yes) & 16 & 76,2 & 34 & 82,9 & 29 & 74,4 & 79 & 78,2 & 0,63 \\
\hline Drugs consumption & 8 & 40 & 18 & 46,2 & 18 & 46,2 & 44 & 44,9 & 0,77 \\
\hline Smoking at least 6 months & 12 & 60 & 22 & 55 & 15 & 38,5 & 49 & 49,5 & 0,19 \\
\hline Have children & 1 & 25 & 3 & 37,5 & 2 & 25 & 6 & 30 & 0,76 \\
\hline Age (mean) & \multicolumn{2}{|c|}{21,95} & \multicolumn{2}{|c|}{22,24} & \multicolumn{2}{|c|}{22,03} & \multicolumn{2}{|c|}{22,1} & 0,90 \\
\hline
\end{tabular}


other beverages (quantity and frequency), among others. The Ethics/Bioethics Committee at the University of Tarapacá and the Health Service of Coquimbo approved research protocols.

Boron exposure assessment. We assessed B exposure based on Boron levels in urine and tap water samples from the volunteers and their houses. Details about sample and analytic determination were published previously (Cortés et al.). In both kinds of samples Inductively Coupled Plasma Mass Spectrometry (ICP-MS) was used in certificated laboratory. According these results, we have establish that in the city of Arica there are three areas with different levels of Boron in tap water high levels (> $7 \mathrm{mgL}-1)$ located in the north, medium levels (3-7 mgL-1) in the center and low levels $(<3 \mathrm{mgL}-1)$ in the south areas of the city. Based on their highest Boron level measured in urine and tap water, volunteers were classified in high, medium or low exposure; cut points for each of these categories were determined as the 50 percentile and 75 percentile of levels of Boron in urine and tap water, shown in Table I (Cortés et al.).

Collection and analysis of semen samples. Method of sperm sampling and analysis has been described (EspinozaNavarro et al., 2010). In short, we followed international WHO recommendations (WHO, 2001; WHO, 2010). Semen samples were obtained after at least 4 days of sexual abstinence, by masturbation and ejaculation and received in a polyethylene bottle of $50 \mathrm{ml}$ sterile. Samples were collected in a room outfitted to ensure the privacy of the participants.

The samples were stored at $37{ }^{\circ} \mathrm{C}$ for $20 \mathrm{~min}$ for liquefaction and after 60 minutes volume, $\mathrm{pH}$, color, odor, consistency, appearance, liquefaction, sperm count, sperm concentration overall, sperm motility, sperm viability and morphology were analyzed. Sperm count to an aliquot of $20 \mu \mathrm{L}(1: 10)$ was used in a solution of formaldehyde and eosin yellow, using a Neubauer hemocytometer. The total sperm count was calculated as the product of seminal volume and sperm concentration. The sperm motility was determined in a direct sample of $10 \mathrm{~L}$, determining the percentage of rapid spermatozoa $(\mathrm{A})$, slow $(\mathrm{B})$, non-progressive $(\mathrm{C})$ and immobile (D). The vitality was assessed by the staining method eosin-nigrosin, determining the percentage of live sperm unstained. For sperm morphology samples were fixed and stained with the Papanicolaou method and analyzed with strict criteria (WHO, 2010). Motility, vitality and sperm morphology were evaluated in 200 sperm. Semen samples were discarded after the analysis performed.

Semen parameters were analyzed blindly from the subjects exposure, indicating the minimum and maximum values and percentages for volume, $\mathrm{pH}$, sperm count, percentage of normal or abnormal shapes (morphology), type of abnormality (head, tail or cytoplasmic droplet), percentage of motility (A grade motility included very rapid sperm; B grade motility included rapid sperm) and percentage of sperm vitality. Motility and vitality were measured at hour 1 and hour 3 after collecting the semen samples.

Statistical analyses. We use descriptive statistics and after we identified whether there were significant differences between the values of each parameter according to each exposure levels defined in urine or water. We use KruskallWallis test and Chi-square test to explore statistically significant differences among the three exposure groups. Data were analyzed with statistical software SPSS for Windows, version 17 (SPSS Inc, Chicago, III, 2006).

Table II. Boron exposure strata and semen characteristics in voluntary participants, Arica, Chile.

\begin{tabular}{|c|c|c|c|c|c|c|c|}
\hline \multirow{3}{*}{$\begin{array}{r}\text { Exposure strata } \\
\text { Seminal parameters }\end{array}$} & \multirow{2}{*}{\multicolumn{2}{|c|}{$\begin{array}{l}\text { Low exposure }\left(\mathrm{mgL}^{-1}\right) \\
\text { B Urine } \leq 2.94 \text { or } \\
\text { B tap water } \leq 3.0\end{array}$}} & \multirow{2}{*}{\multicolumn{2}{|c|}{$\begin{array}{l}\text { Medium }\left(\mathrm{mgL}^{-1}\right) \\
\text { B Urine } 2.95-7.4 \text { and } \\
\text { B tap water } 3.0-7.0\end{array}$}} & \multirow{2}{*}{\multicolumn{2}{|c|}{$\begin{array}{l}\text { High }(\mathrm{mgL}-1) \\
\mathrm{B} \text { in urine } 7.4-17.4 \text { or } \\
\text { tap water } 7-11.0\end{array}$}} & \multirow[b]{3}{*}{ P-value } \\
\hline & & & & & & & \\
\hline & Median & $\mathrm{p} 25-\mathrm{p} 75$ & Median & $\mathrm{p} 25-\mathrm{p} 75$ & Median & $\mathrm{p} 25-\mathrm{p} 75$ & \\
\hline Volume (ml) & 2,5 & $1.65-3.9$ & 2.8 & $1.8-4.0$ & 2.5 & $1.8-3.5$ & 0.92 \\
\hline $\mathrm{pH}$ & 8 & $7.0-8.0$ & 81 & $7.5-8.0$ & $8.0^{1}$ & $7.0-8.0$ & 0.079 \\
\hline $\mathrm{N}^{\circ}$ sperm $/ \mathrm{mL}$ & 45,106 & $17.18-90.50$ & 48.25 & $30.5-82.0$ & 38.0 & $19.5-93.0$ & 0.72 \\
\hline Abnormal morphology (\%) & 83,3 & $80.1-86.4$ & $90.0^{2}$ & $82.0-92.5$ & 83.0 & $79.8-88.9$ & 0.010 \\
\hline Motility $\mathrm{A}+\mathrm{B} 1^{\circ}$ hour & 38.1 & $24.5-65.6$ & 40.0 & $25.0-57.5$ & 45.5 & $29.1-58.0$ & 0.77 \\
\hline Motility $\mathrm{A}+\mathrm{B} 3^{\circ}$ hour & 7.8 & $0.0-21.0$ & 18.0 & $1.3-27.3$ & 8.7 & $0.0-26.1$ & 0.44 \\
\hline Vitality $(\%) 1^{\circ}$ hour & 88.6 & $69.3-94.1$ & 88.0 & $62.1-95.0$ & 76.9 & $70.0-90.0$ & 0.5 \\
\hline Vitality $(\%) 3^{\circ}$ hour & 60.0 & $43.5-80.0$ & 65.0 & $43.0-79.8$ & 47.4 & $30.9-66.0$ & 0.191 \\
\hline Filancia (\%) & 26.7 & & 46.7 & & 26.7 & & 0.576 \\
\hline
\end{tabular}

P-value comparison $^{1} \quad$ high vs medium $=0.0632$ medium vs high $=0.011$ 
Table III. Boron exposure strata and sperm defects. Voluntary participants, Arica, Chile.

\begin{tabular}{|c|c|c|c|c|c|c|c|}
\hline \multirow{3}{*}{$\begin{array}{l}\text { Exposure strata } \\
\text { Sperm shape } \\
\text { Abnormality \% }\end{array}$} & \multirow{2}{*}{\multicolumn{2}{|c|}{$\begin{array}{c}\text { Low exposure }\left(\mathrm{mgL}^{-1}\right) \\
\text { B Urine } \leq 2.94 \text { or } \\
\text { B tap water } \leq 3.0\end{array}$}} & \multirow{2}{*}{\multicolumn{2}{|c|}{$\begin{array}{c}\text { Medium }\left(\mathrm{mgL}^{-1}\right) \\
\text { B Urine 2.95-7.4 and } \\
\text { B tap water 3.0-7.0 }\end{array}$}} & \multicolumn{2}{|c|}{$\operatorname{High}\left(\mathrm{mgL}^{-1}\right)$} & \multirow[b]{3}{*}{ P-value } \\
\hline & & & & & $\begin{array}{l}B \text { in urin } \\
\text { tap water }\end{array}$ & $\begin{array}{l}4-17.4 \text { or } \\
11.0\end{array}$ & \\
\hline & Median & p25 - p75 & Median & p25 - p75 & Median & p25 - p75 & \\
\hline Pointed head & 30 & $19.2-34.7$ & 23.6 & $15.0-30.95$ & 27.5 & $15.0-37.2$ & 0.10 \\
\hline Microcephalous & 11.9 & $5.7-21.4$ & 10.0 & $5.0-15.0$ & 11.1 & $5.0-19.2$ & 0.31 \\
\hline Macrocephalous & 3.4 & $1.7-10.0$ & 5.0 & $3.0-10.0$ & 3.5 & $2.0-5.9$ & 0.16 \\
\hline Bicephalous & 0.0 & $0-2.1$ & 0.0 & $0-1.9$ & 0 & $0-2.0$ & 0.83 \\
\hline Tail defect & 21.3 & $15.2-29.6$ & 25.0 & $18.0-33.2$ & 31.1 & $21.4-36.0$ & 0.102 \\
\hline Cytoplasmic droplet & 5.33 & $3.9-12.5$ & 10.0 & $6.0-15.0$ & 7.1 & $5.0-12.5$ & 0.044 \\
\hline Round cells & 8.9 & $3.9-18.6$ & 9.5 & $6.1-18.9$ & 7.3 & $4.05-17.4$ & 0.247 \\
\hline
\end{tabular}

P-value comparation $\quad 3$ low vs medium $=0.046$

\section{RESULTS}

General characteristics of the study group by exposure are shown in Table I. Participants were comparable regarding alcohol consumption, smoking, drugs use and reproductive success. There are no statistical differences among the three groups.

Boron concentrations in urine and tap water and their relation with semen parameters by level of exposure are shown in Table II. In the medium level of exposure (urinary B between 2.95-7.4 mg.L-1 and B in tap water between 3.0$7.0 \mathrm{mgL}-1 \mathrm{pH}$ shows a slightly alkaline environment, expressing the lowest percent of normal sperm morphology. Motility and vitality in the three hour has the highest values in the medium levels of exposure to boron. In the highest B exposure, sperm presented the best levels of normal morphology and motility in the first hour being statistically significant (Table II). None of other parameters reached statistical significance when comparing the exposure groups.

Changes in morphology according boron levels exposure are shown in Table III. In the medium exposure there are more immature cells, among them gonias, primary and second spermatocytes, spermatids and also white blood cells. With the highest exposure the most relevant is tail defect.

\section{DISCUSSION}

Numerous environmental contaminants have been shown as disrupters of sperm quality in male workers, affecting concentration, motility and sperm morphology (Jurewicz et al.; Lifeng et al., 2006; Wirth et al., 2007). It is imperative to become more aware of the factors that may affect semen quality and avoid parental exposure to these hazards, which may affect human reproduction.

Volunteers evaluated here formed a homogeneous group, as they shared certain characteristics such as being healthy, living in the city of Arica for at least two years, being 18 to 30 years old and having similar lifestyle patterns (alcohol consumption or smoking, Table I). These similar conditions allowed control of these factors among the three groups evaluated. However, it should be noted that the sample size was established for convenience, so these results are not representative of the entire population and are applicable only for this group.

In Arica there was evidence of past exposures to arsenic and lead by soil. Both elements were evaluated in drinking water and urine was evaluated. Results not shown here reporting for arsenic, reported median levels of $6 \mu \mathrm{gL}-$ 1 in drinking water and $216 \mu \mathrm{gL}-1$; for lead the median values were $26 \mu \mathrm{gL}-1$ in drinking water and $3 \mu \mathrm{gL}-1$ in urine; there were not differences between groups.

Other factors that could have affected the quality of the studied parameters were not assessed (i.e. follicle stimulating hormone, luteinizing hormone and testosterone levels); only the survey data were used to identify patients who presented cryptorchidism, varicocele or reproductive success (Espinoza-Navarro, et al.).

Although no statistically significant differences were observed for volume, $\mathrm{pH}$, concentration, motility, vitality, filament (gelatinous semen filament), when comparing increasing levels of Boron in tap water or urine, our results showed a biological effect in the group with 
the medium exposure to Boron. This biological effect was evidenced by a highest percentage in sperm count ( 48.28 versus 45.1 or $38.0 \mathrm{Mml}-1$ for low or high exposure) and filament (46.7 versus $26.7 \%$ both for low or high exposure) when volunteers residing in the area with levels of Boron between 3 and $7 \mathrm{mgL}-1$ and have urinary levels between 2.95 to $7.4 \mathrm{mgL}-1$ (Table II).

Regarding the morphology, was noted that in areas with medium exposure to boron, abnormal morphology was highest $(90.0 \%$ versus 83.3 or $83.0 \%$ for low or high exposure), statistically significant ( $\mathrm{p}$ value $=0.01$ ). Duydu et al., did not find significant differences in sperm morphology in workers exposed to Boron in tap water which levels reached a maximum value of $9.47 \mathrm{mgL}-1$.

Abnormalities in sperm head (pointed head) and tail defect increased in the area with the highest Boron level in tap water or urine, not being statistically significant. Other authors identified no damage attributable to Boron in highly exposed Chinese workers (Scialli et al.; Robbins et al.). Our results only show significant differences by abnormalities of cytoplasmic droplet, with the highest value in the medium group ( $\mathrm{p}$ value $=0.04$ ).

The results observed for the group with the highest exposure represent a contribution to the discussion about the role of Boron in reproductive processes with increased normal sperm morphology, decreased sperm concentration and vitality. The medium exposure group evidenced a wider range of $\mathrm{pH}$, abnormal sperm morphology and motility and vitality (3th hour). These results suggest that an optimal behavior of the seminal parameters would be expressed at average levels with excretion values of boron in urine from 2.95 to $7.38 \mathrm{mgL}-1$ or living in areas with Boron in tap water between 3 to $7 \mathrm{mgL}-1$. These findings could be interpreted like a " $U$ " dose-response relationship in itself. It is necessary to establish if there are compensatory effects, suggesting a beneficial effect of certain level of boron exposure on maintaining the normal sperm morphology. These results state that studies about boron contamination should continue in order to define on a scientific basis the permitted levels of boron in drinking water (Weinthal et al.).

\section{CONCLUSIONS}

Young men exposed to B in drinking water present variations in the sperm characteristics associated with the level of exposure. Most of these changes are positive at intermediate levels of B. But at highest exposures there were negative changes in sperm morphology, concentration, motility and vitality, all relevant parameters of fertility. Thus our study suggests a U curve for effects of B in sperm: having the best result at intermediate levels of exposure, in agreement with its micronutrient classification.

\section{ACKNOWLEDGEMENTS}

This work was funded partly by the Ministry of Health of Chile (period 2006-2009) and by Major Project UTA 4712-13. Related research is supported by CONICYTFONDAP 15130011. Its contents are solely the responsibility of the authors and do not necessarily represent the official views of the awarding agencies. The authors deeply acknowledge the collaboration of the population from Arica, Chile.

CORTÉS, S.; ESPINOZA-NAVARRO, O. \& FERRECCIO, C. Exposición elevada a boro en el agua potable y parámetros de esperma en gente joven chilena. Int. J. Morphol., 35(1):99-104, 2017.

RESUMEN: El objetivo de este trabajo fue describir los parámetros espermáticos en residentes del norte de Chile. Se evaluaron en 101 voluntarios (18 y 30 años), los niveles urinarios y de agua potable de boro, usando "Inductively Coupled Plasma Mass Spectrometry”. Los parámetros del semen se midieron con métodos estandarizados. Cada individuo se clasificó en 3 niveles de exposición: bajo (niveles B en la orina $\leq 2,94 \mathrm{mgL}-1$ o agua potable $\leq 3,0 \mathrm{mgL}-1$ ), medio (B urinario entre 2,95-7,4 mgL-1 y B en agua de beber con 3,0- 7,0 mgL1) y alto (B urinario $>7,4 \mathrm{mgL}-1$ o agua potable $>7,0 \mathrm{mgL}-1$ ). No se encontraron diferencias significativas entre los grupos por $\mathrm{pH}$, concentración de espermatozoides $(45,1 ; 48,2$ y 38 millones $/ \mathrm{mL})$, motilidad a $1^{\mathrm{a}}$ hora $(38,1 ; 40,0$ y $45,5 \%)$ y vitalidad $1^{\mathrm{a}}$ hora $(88,6 ; 88,0$ y 76,9\%) respectivamente. La morfología anormal fue significativamente diferente $(83,3 ; 90$ y $83 \%)$. Los hombres jóvenes expuestos a $\mathrm{B}$ en el agua potable presentan variaciones espermáticas asociadas con el nivel de exposición. La mayoría de estos cambios son positivos en niveles intermedios de B. Para las exposiciones más altas se observaron cambios negativos en la morfología, concentración, motilidad y vitalidad del esperma, parámetros relevantes de la fertilidad. Un efecto beneficioso se observa en la exposición media, como una "curva U".

PALABRAS CLAVE: Semen; Fertilidad; Exposición al boro; Jóvenes; Chile. 


\section{REFERENCES}

Cortés, S.; Reynaga-Delgado, E.; Sancha, A. M. \& Ferreccio, C. Boron exposure assessment using drinking water and urine in the North of Chile. Sci. Total Environ., 410-1:96-101, 2011.

Duydu, Y.; Basaran, N.; Üstündag, A.; Aydin, S.; Ündeger, Ü.; Ataman, O. Y.; Aydos, K.; Düker, Y.; Ickstadt, K.; Waltrup, B. S.; Golka, K. \& Bolt, H. M. Reproductive toxicity parameters and biological monitoring in occupationally and environmentally boron-exposed persons in Bandirma, Turkey. Arch. Toxicol., 85(6):589-600, 2011.

Espinoza Navarro, O.; Cortes A., S.; Monreal, J. \& Ferreccio, C. Spermograms of healthy young subjects living in Arica, Chile. Rev. Med. Chil.,138(12):1510-6, 2010.

Esteban, M. \& Castaño, A. Non-invasive matrices in human biomonitoring: a review. Environ. Int., 35(2):438-49, 2009.

Fail, P. A.; Chapin, R. E.; Price, C. J. \& Heindel, J. J. General, reproductive, developmental, and endocrine toxicity of boronated compounds. Reprod. Toxicol., 12(1):1-18, 1998.

Giudice, L. C. Infertility and the environment: the medical context. Semin. Reprod. Med., 24(3):129-33, 2006.

Hauser, R. The environment and male fertility: recent research on emerging chemicals and semen quality. Semin. Reprod. Med., 24(3):156-67, 2006.

Jurewicz, J.; Hanke, W.; Radwan, M. \& Bonde, J. P. Environmental factors and semen quality. Int. J. Occup. Med. Environ. Health, 22(4):30529, 2009.

Korkmaz, M.; Yenigün, M.; Bakırdere, S.; Ataman, O. Y.; Keskin, S.; Müezzinoglu, T. \& Lekili, M. Effects of chronic boron exposure on semen profile. Biol. Trace Elem. Res., 143(2):738-50, 2011.

Korkmaz, M.; Uzgören, E.; Bakirdere, S.; Aydin, F. \& Ataman, O. Y. Effects of dietary boron on cervical cytopathology and on micronucleus frequency in exfoliated buccal cells. Environ. Toxicol., 22(1):17-25, 2007a.

Korkmaz, M.; Sayli, U.; Sayli, B. S.; Bakirdere, S.; Titretir, S.; Yavuz Ataman, O. \& Keskin, S. Estimation of human daily boron exposure in a boron-rich area. Br. J. Nutr., 98(3):571-5, 2007b.

Lifeng, T.; Shoulin, W.; Junmin, J.; Xuezhao, S.; Yannan, L.; Qianli, W. \& Longsheng, C. Effects of fenvalerate exposure on semen quality among occupational workers. Contraception, 73(1):92-6, 2006.

Murray, F. J. A comparative review of the pharmacokinetics of boric acid in rodents and humans. Biol. Trace Elem. Res., 66(1-3):331-41, 1998.

Nielsen, F. H. Ultratrace elements in nutrition. Annu. Rev. Nutr., 4:21-41, 1984.

Robbins, W. A.; Xun, L.; Jia, J.; Kennedy, N.; Elashoff, D. A. \& Ping, L. Chronic boron exposure and human semen parameters. Reprod. Toxicol., 29(2):184-90, 2010.

Robbins, W. A.; Wei, F.; Elashoff, D. A.; Wu, G.; Xun, L. \& Jia, J. Y:X sperm ratio in boron-exposed men. J. Androl., 29(1):115-21, 2008.

Rose, V. E. \& Cohrssen, B. (Eds.). Patty's Industrial Hygiene. $6^{\text {th }}$ ed. London, Wiley, 2010.

Scialli, A. R.; Bonde, J. P.; Brüske-Hohlfeld, I.; Culver, B. D.; Li, Y. \& Sullivan, F. M. An overview of male reproductive studies of boron with an emphasis on studies of highly exposed Chinese workers. Reprod. Toxicol., 29(1):10-24, 2010.

Sifakis, S.; Mparmpas, M.; Soldin, O. P. \& Tsatsakis, A. Pesticide Exposure and Health Related Issues in Male and Female Reproductive System. In: Stoytcheva, M. (Ed.). Pesticides - Formulations, Effects, Fate. Intech Open Science Open Minds, 2011. pp.495-526.

Telöken, C.; Juncal, S. \& Graziottin, T. M. Environmental Factors. In: Parekattil, S. J. \& Agarwal, A. (Eds.). Male Infertility. Contemporary Clinical Approaches, Andrology, ART \& Antioxidants. New York, Springer, 2012. pp.283-95.

Usuda, K.; Kono, K.; Dote, T.; Watanabe, M.; Shimizu, H.; Tanimoto, Y. \& Yamadori, E. An overview of boron, lithium, and strontium in human health and profiles of these elements in urine of Japanese. Environ. Health Prev. Med., 12(6):231-7, 2007.

Weinthal, E.; Parag, Y.; Vengosh, A.; Muti, A. \& Kloppmann, W. The EU Drinking Water Directive: the boron standard and scientific uncertainty. Environ. Policy Gov., 15(1):1-12, 2005.

World Health Organization (WHO). Guidelines for Drinking-water Quality. $3^{\text {rd }}$ ed. Geneva, World Health Organization, 1993. pp.45-6.

World Health Organization (WHO). Laboratory manual of the WHO for the examination of human semen and sperm-cervical mucus interaction. Ann. Ist. Super. Sanita, 37(1):I-XII, 1-123, 2001.

World Health Organization (WHO). WHO Laboratory Manual for the Examination and Processing of Human Semen. $5^{\text {th }}$ ed. Geneva, World Health Organization, 2010.

Wirth, J. J.; Rossano, M. G.; Daly, D. C.; Paneth, N.; Puscheck, E.; Potter, R. C. \& Diamond, M. P. Ambient manganese exposure is negatively associated with human sperm motility and concentration. Epidemiology, 18(2):270-3, 2007.

Xing, X.; Wu, G.; Wei, F.; Liu, P.; Wei, H.; Wang, C.; Xu, J.; Xun, L.; Jia, J.; Kennedy, N.; Elashoff, D. \& Robbins, W. Biomarkers of environmental and workplace boron exposure. J. Occup. Environ. Hyg., 5(3):141-7, 2008.

\section{Corresponding author: Omar Espinoza-Navarro Universidad de Tarapacá Arica \\ CHILE}

\section{Email: omarespinoza091@gmail.com}

Received: 03-12-2016

Accepted: 22-12-2016 